\title{
A pilot study to investigate if New Zealand men with prostate cancer benefit from a Mediterranean-style diet
}

Sharon Erdrich, Karen S Bishop, Nishi Karunasinghe, Dug Yeo Han, Lynnette R Ferguson

Carcinoma of the prostate is the most commonly diagnosed malignancy and the third leading cause of mortality in New Zealand men, making it a significant health issue in this country. Global distribution patterns suggest that diet and lifestyle factors may be linked to the development and progression of this cancer. Twenty men with diagnosed prostate cancer adhered to a Mediterranean diet, with specific adaptations, for three months.

Prostate-specific antigen, C-reactive protein and DNA damage were evaluated at baseline and after three months of following the diet. Dietary data were collated from diet diaries and an adaptation of a validated Mediterranean diet questionnaire. A significant reduction in DNA damage compared to baseline was apparent, with particular benefit noted for overall adherence to the diet $(p=0.013)$, increased intake of folate $(p=0.023)$, vitamin $C$ $(p=0.007)$, legumes $(p=0.004)$ and green tea $(p=0.002)$. Higher intakes of red meat and dairy products were inversely associated with DNA damage $(p=0.003$ and $p=0.008$ respectively). The results from this small feasibility study suggest that a high-antioxidant diet, modelled on Mediterranean traditions, may be of benefit for men with prostate cancer. Protection against DNA damage appears to be associated with the diet implemented, ostensibly due to reduction in reactive oxidant species. These findings warrant further exploration in a longer trial, with a larger cohort. 


\section{A Pilot Study to Investigate if New Zealand Men with 3 Prostate Cancer Benefit from a Mediterranean-Style Diet}

4 Sharon Erdrich ${ }^{1, *}$, Karen S. Bishop ${ }^{2}$, Nishi Karunasinghe ${ }^{3}$, Dug Yeo Han ${ }^{3}$ and

5 Lynnette R.Ferguson ${ }^{1,3}$

61 Discipline of Nutrition, FM\&HS, University of Auckland, Private Bag 92019, Auckland

$7 \quad 1142$,

$8 \quad$ New Zealand; E-Mail: 1.ferguson@auckland.ac.nz

92 Auckland Cancer Society Research Centre, FM\&HS, University of Auckland, Private Bag

109 92019, Auckland 1142, New Zealand; E-Mail: k.bishop@auckland.ac.nz

113 Nutrigenomics New Zealand, University of Auckland, Private Bag 92019, Auckland 1142,

12 New Zealand; E-Mails:n.karunasinghe@auckland.ac.nz;dy.han@auckland.ac.nz

13 * Author to whom correspondence should be addressed: E-Mail: sharon@houseofhealth.co.nz; 14 Tel.: +64-9-377-7070; Fax: +64-9-820-6498. 
On a global scale, prostate cancer is an important health consideration. It is the fourth most common cancer internationally, and in men ranks second only to lung cancer(Ferlay et al., 2012). Prostate cancer incidence is highest in developed nations, compared to less-developed countries, a difference that is only partially explained by the higher use of prostate specific antigen (PSA) as a screening tool in developed nations(Center et al., 2012). In New Zealand, cancer of the prostate is the third most common cause of cancer-related mortality, with death rates disproportionately higher in Māori men (28.7 c.f. 16.7 deaths per 100,000 (age-standardised rates per 100,000 male population, standardised to the WHO world standard population)( $\mathrm{MOH}, 2013)$.

Worldwide patterns of prostate cancer incidence and mortality support the hypothesis that diet and lifestyle are likely contributors to both development and progression of this malignancy.Furthermore, alterations in risk associated with migratory patterns and the westernisation of dietary patterns associated with globalisation (Baade, Youlden \& Krnjacki, 2009; Melnik, John \& Schmitz, 2011)give added credence to this theory.

Chronic inflammation and infection have been implicated in the development of around onefifth of all cancers(Greene et al., 2011), including prostate cancer (Gurel et al., 2014).Other influences include genetic and epigenetic factors(Pantuck et al., 2006), imbalances between reactive oxygen species and antioxidants, and DNA damage (Waris \& Ahsan, 2006)(Figure 1).

The role of inflammation in prostate cancer is unclear.Elevated levels of inflammatory markers have been associated with high-grade prostate cancer in some studies(Shariat et al., 2001; Platz \& De Marzo, 2004; Huffman et al., 2006; Gurel et al., 2014)but not in others(Il'yasova et al., 2005; Stark et al., 2009). Systemic inflammation has been associated with earlier cancer mortality(McArdle, Qayyum \& McMillan, 2010; Shafique et al., 2012), which adds weight to an argument for a detrimental effect of chronic inflammation and the potential benefit of alow-inflammatory diet.

Increased levels of free radicals and pro-oxidant compounds (Arsova-Sarafinovska et al., 2009; Qu et al., 2013; Kanwal et al., 2014), and decreased levels of antioxidant enzymes have been found in prostate tissue (Kanwal et al., 2014), and in association with prostate cancer(Arsova-Sarafinovska et al., 2009). Both prostatic cancer cells and high-grade prostatic intraepithelial neoplasia are notably deficient in the important endogenous antioxidant, glutathione $S$-transferase(Platz \& De Marzo, 2004). This may be due to inflammation-induced inactivation of genes that have roles in cellular protection and restoration of damaged DNA (Kundu \& Surh, 2012). Reduction in the ability of cells to produce protective antioxidants may occur due to alterations in cell morphology, leaving the prostate vulnerable to damage by carcinogenic compounds that might otherwise be neutralised by antioxidants. Indeed, proliferative inflammatory atrophy, a precursor to development of prostate cancer, is a cellular change that is postulated to be the result of cell damage(Platz \& De Marzo, 2004; Brawer, 2005). 
The Mediterranean diet has been extensively examined and its benefits in terms of reductions in oxidative stress and inflammation are generally well-accepted (Urpi-Sarda et al., 2012; Viscogliosi et al., 2013). This dietary style is centered on consumption of high amounts of extra virgin olive oil, fruit and vegetables, pulses and legumes, whole-grains, and poultry, along with some fish and seafood. Intake of red meat, dairy products and processed or refined foods is traditionally low (Couto et al., 2011). Deviation away from such a pattern, towards a more western-style diet, has been associated with increased prostate cancer incidence (Ambrosini et al., 2008; Stott-Miller, Neuhouser \& Stanford, 2013). Coutoet al.(Couto et al., 2011) examined data from the large European Prospective Investigation into Cancer and Nutrition (EPIC) study and concluded that a Mediterranean diet is particularly beneficial in protecting against breast, colon, and prostate cancer.

The brassica family is not emphasised in general Mediterranean diet guidelines. However, this family of vegetables has attracted much interest in recent years, primarily on account of the levels of glucosinolates, which are particularly high in broccoli (Moreno et al., 2006). Nutrigenomic effects of broccoli are discussed in detail in Ferguson andSchlothauer(Ferguson \& Schlothauer, 2012).

Pomegranate, and its juice, has received a great deal of attention related to potential chemoprotective effects, including beneficial effects in slowing of prostate-specific antigen (PSA) doubling time in men with prostate cancer (Pantuck et al., 2006, 2009; Paller et al., 2012). This benefit is attributed to high levels of polyphenols (particularly punicalagin, an elligatannin(Koyama et al., 2010)), that contribute to pomegranate's overall antioxidant capacity, which is greater than either red wine or green tea (Gil et al., 2000). Polyphenols are also high in extra virgin olive oil, red wine, and green tea (Tuck \& Hayball, 2002). These phytochemicals have demonstrable epigenetic effects(Joven et al., 2013), which may account for at least some of the benefits attributed to their consumption. As pomegranate is found throughout the Mediterranean area, it is logical to assume it would be commonly consumed in the region. However, this has not been reported in nutritional research which focuses on Mediterranean dietary patterns. It is quite possible that pomegranate may be a contributor to documented advantages associated with diets in the Mediterranean region.

High fibre diets, including consumption of legumes and whole grains, have been linked to a wide range of health benefits. Legumesare an important food group in the Mediterranean diet (Ferrís-Tortajada et al., 2012), and have been associated with reduced prostate cancer risk (Chan, Lok \& Woo, 2009). Consumption of legumes (particularly soy) is significant in Asian diets where prostate cancer incidence is also low (Chan, Lok \& Woo, 2009). Mechanisms for benefit are numerous and include: high fibre content, which may be advantageous by reduction of postprandial glycaemia (Gropper, Stepnick \& Smith, 2013), lower levels of insulin-like growth factor (Landberg et al., 2010), and increases in sex hormone binding globulin (Tymchuk et al., 1998). The minimisation of post-prandial rises in blood sugar level is desirable in men with prostate 
cancer, due to glycaemia-associated increases in markers of inflammation and oxidative stress(Rytter et al., 2009). Additionally, foods that promote a high glycaemic response induce insulin and insulin-like growth factor (Melnik, John \& Schmitz, 2011), which may contribute to prostate cancer progression(Chan et al., 2002).

In some studies (Gao, LaValley \& Tucker, 2005; Koh et al., 2006; Allen et al., 2008), but not all (Huncharek, Muscat \& Kupelnick, 2008; Pettersson et al., 2012), consumption of dairy foods has been linked to higher risk of developing prostate cancer. Risk has been associated with the quantity consumed (Allen et al., 2008) and dairy intake during adolescence (Torfadottir et al., 2012). Prostate cancer mortality has also been correlated to milk consumption(Ganmaa et al., 2002). While these data are inconclusive, it does, nonetheless, raise concerns over the recommendation of dairy as a source of calcium for men at risk of developing osteoporosis, including those with prostate cancer who have had hormonal ablation treatment (Malcolm et al., 2007).

Fish is not considered a major component of Mediterranean diets (Trichopoulou et al., 2005), but is generally considered preferential to red meat for men with prostate cancer (Terry et al., 2001; Chavarro et al., 2008; Bosire et al., 2013). Fish is regarded as a good source of omega-3 polyunsaturated fatty acids, promoting anti-inflammatory pathways (Jain et al., 2008), which has been considered to be desirable in men for whom lowering inflammation is a goal. However, the benefit of omega-3 polyunsaturated fatty acids in prostate cancer has recently been challenged(Brasky et al., 2013). The role of dietary fats in prostate cancer is discussed in more detail by Bishop,et al(Bishop et al., 2015).

Green tea is not a dietary feature in the Mediterranean region, but is a common beverage in East Asian countries, where mortality rates from prostate cancer are the lowest, globally (Ferlay et al., 2012). A mounting volume of evidence supports the recommendation of consumption of green tea, due to its antioxidant potential, largely from polyphenols, in particular epigallocatechin-3-gallate (EGCG) (Du et al., 2012). EGCG has documented anti-proliferative properties (Du et al., 2012)and affords protection to DNA in prostate cells (Kanwal et al., 2014). Furthermore, green tea consumption has been associated with lower prostate cancer incidence (Zheng et al., 2011) and reduced risk of progression to advanced disease (Kurahashi et al., 2008).

This pilot study was undertaken to establish bothfeasibility and likely benefit of three months of adherence to a Mediterranean dietary pattern, with specific modifications, on DNA damage and inflammation in New Zealand men with prostate cancer.

\section{Materials and Methods}

Written approval for this pilot study was granted by the Northern Y Regional Ethics Committee (New Zealand), study reference NTY/11/11/109. 
126

127

128

129

130

131

132

133

134

135

136

137

138

139

140

141

142

143

144

145

146

147

148

149

150

151

152

153

154

155

156

157

158

159

160

161

162

Study volunteers with Gleason score $6-7(3+3$ or $3+4)$ who had participated in an earlier study investigating DNA damage and genotypes (Karunasinghe et al., 2012)were invited to enrol in this dietary intervention. Men with lower Gleason scores were selected preferentially to minimise the possible confounding effect of advanced disease. Other criteria for inclusion were: under 75 years of age, no diagnosis of diabetes, no evidence of progressionand not currently receiving treatment for prostate cancer (hormonal therapyexcepted), and with no history of other cancer except treated skin carcinomas.

The dietary guidelines were in accordance with general Mediterranean patterns as per a validated tool (Martinez-Gonzalez et al., 2012) with specific adaptations.

Men were given nutritional counselling at enrolmentby nutritional specialistson the study team and coached regarding the dietary guidelines. Both hard and soft copies of a comprehensive compilation of recipes incorporating the main foods and principles of the diet were provided. Additional support and clarification was provided on an as-needed basis. As a goal of this study was to determine the degree of acceptance of this pattern of eating in the lifestyle of New Zealand men, the intervention was based around general principles with specific recommendations, as summarised in Table 1 , rather than a prescriptive diet.

All participants were provided withNew Zealand-produced extra virgin olive oil with a polyphenol level of $233 \mathrm{mg} / \mathrm{kg}$ ( $1 \mathrm{~L} / \mathrm{month})$, fresh frozen salmon ( $200 \mathrm{~g} /$ week), unsweetened pure pomegranate juice $(1 \mathrm{~L} /$ week) and samples of a variety of canned legumes. These were donatedby New Zealand distributors: Oil Seed Extractions Ltd., Ashburton;Aoraki Smokehouse Salmon, Twizel; Life Juices, Auckland, and Delmaine Fine Foods, Auckland, respectively, and given to the volunteers at enrolment.

The validated 14-point Mediterranean diet adherence questionnaire published by MartinezGonzalez(Martinez-Gonzalez et al., 2012)was adapted to be consistent with the recommendations. Thequestionnaire was completed bystudy participants, along with four-day diet diaries, at the beginning and conclusion of the study (Table 2). Adherence questionnaires were scored out of 20. Serving sizes were estimated and recorded both in diet diaries and the dietary adherence questionnaire.Diet diaries were analysed using FoodWorks ${ }^{\circledR} 7$ (Xyris 2012, Xyris Software (Australia)Pty Ltd, Brisbane, Australia).

Blood samples were collected at baseline, and again at three months of follow-up, (plain, EDTA, Heparin and SST II Advance Vaccutainers), and processed within 2 hours of collection. C-reactive protein and PSA were tested using enzyme immunoassaysperformed by LabTests, Auckland, New Zealand.

Comet assays were performed on both fresh blood and hydrogen-peroxide challenged samples as described by Karunasingheet aland Fergusonet al(Karunasinghe et al., 2004; Ferguson et al., 2010). As the data were skewed, figures for percentage tail DNA were log-transformed and the back-transformed mean was used for the analysis. 
163 Statistical evaluation was performed using SAS (v9.2 SAS Institute, Cary, NC, USA).

164 Correlations were examined using Spearman's rho. The Student's paired $t$-Test was used to

165 evaluate differences between baseline and study-end.

166

167

168

169

170

171

172

173

174

175

176

177

178

179

180

181

182

183

184

185

186

187

188

189

190

191

192

193

194

195

196

197

198

\section{Results}

A total of twenty-eight men were enrolled in the study. While we sought to enrol men on active surveillance protocols, a low response rate resulted in the recruitment of those who had received treatment for $\mathrm{PCa}$ but within the Gleason score range specified.Eight men were not included in the final analysis: four were lost to follow-up for a variety of reasons, two dropped out of the study due to life stresses, one had difficulty conforming to the diet and one was eliminated due to unreliability of dietary information provided. The characteristics for the remaining twenty participants are presented in Table 3.

Data on tumour staging was available for half of the cohort. Using the Tumour (T), Node (N), Metastasis (M) grading system, grades were T1-T3, N0 and M0.

Of the twenty participants in the final analysis, none were current smokers. Mean time since smoking cessation was 31 years $(\mathrm{SD}=13)$. Past history of smoking of less than one pack-year was regarded as a "never-smoker". Pack-year history was positively associated with the use of Aspirin and/or Diclofenac ( $p=0.007)$.

Over the course of the study two men ceased taking and one commenced low dose Aspirin.Another participant discontinued use of Diclofenac during the study period.

Of this somewhat sedentary group of men, $70 \%$ were overweight or obese (BMI $>25 \mathrm{~kg} / \mathrm{m}^{2}$ ). Mean body weight reduced by $2.3 \mathrm{~kg}(95 \%$ CI $1.11-3.49, p<0.001)$ over the course of the study. There was a mean reduction in body mass index of $0.85 \mathrm{~kg} / \mathrm{m}^{2}(95 \%$ CI $0.52-1.18$, $p<0.001)$.

Men who were less active tended to have higher levels of C-reactive protein $(p=0.003)$. This association remained at study end, albeit slightly weaker $(p=0.055)$.

At baseline, dietary scores for the targeted Mediterranean-style pattern were low.Mean adherence was 6.3 (SE 0.69), with individual scores ranging from 2 to 13 (of a maximum of 20).At three months of follow-up, mean adherence was 13.63 (SE 0.49), range 9 to 17. The mean change in dietary adherence from baseline to study end was +7.33 (95\% CI 5.76-8.89), which was highly significant $(p<0.001)$.

There were no statistically significant relationships between dietary adherence and either Creactive protein or PSA at either baseline or three months.

Improvements were noted in all areas evaluated on the adherence questionnaire, with the exception of servings of fruit, vegetables, use of sofrito(tomato-based sauce prepared with garlic and/or onion), the intake of sweetened beverages, and wine. Pooled group adherence scores are presented in Table 4. 
Estimated energy requirements and reported energy intakewere calculated using FoodWorks ${ }^{\circledR} 7$ software, from recorded body weights, reported energy expenditure and diet diaries (Table 5). There was a tendency to under-report energy intake. This was not statistically significant at baseline (SE 280, 95\% CI 108-1063, $p=0.10$ ). At the end of the study period, the difference reached statistical significance, with reported energy intake a mean 720 kilojoules lower than estimated requirements (SE 194, 95\% CI 314-1125, $p=0.007$ ).

Energy obtained from saturated fat, as \% of total energy intake, decreased significantly $(p<0.001)$. Other sources of energy did not alter significantly over the course of the study (Figure 2).

Increases in intake of broccoli, sofrito, and pomegranate juice were statistically significant, as was a decrease in refined carbohydrate intake (per reported intakes of sweetened beverages and baked goods) (Table 6). The reduction in carbohydrate intake was not significant. No change was observed in regards to intake of fruit, vegetables, dietary fibre, or total sugar. It was apparent that the source of dietary sugars shifted away from sucrose and lactose, towards fructose and glucose.

Participants significantly reduced their consumption of red meat $(p<0.001)$, and increased their intake of fish $(p<0.001)$, and legumes $(p=0.005)$, with no net change in protein intake(Table 7).

Alterations in dietary fats and associated relationships are discussed in detail in Bishop, et al(Bishop et al., 2015).

Reductions in DNA damage were noted after three months of the dietary intervention. This did not reach significance for basal (fresh-blood) DNA damage ( $p=0.075)$, but was highly significant for peroxide-induced DNA damage $(p=0.009)$.

Spearman bivariate correlation was used to identify relationships between DNA damage at study end and intake of the items specified on the adherence questionnaire and data generated from diet diaries. Overall, following the dietary pattern was inversely associated with DNA damage $(p=0.013)$. DNA damage was also inversely associated with consumption of green tea and intake of legumes ( $p=0.002$ and $p=0.004$ respectively), and positively associated with red meat intake $(p=0.007)$. Intake of dairy products and margarine/butter/cream was also correlated with DNA damage at study end. These results are discussed in Bishopet al.(Bishop et al., 2015). No significant relationships were noted between DNA damage and vegetable, fruit, or pomegranate intake.

An inverse association between DNA damage and vitamin $\mathrm{C}$ intake was apparent. This was weak at baseline ( $p=0.098)$, and became significant at studyend $(p=0.007)$. Dietary folate intake at three months was inversely associated with hydrogen peroxide-induced DNA damage $(p=0.023)$. Vitamin E intake, which increased significantly (Table 4$)$, was inversely associated with both basal and peroxide-induced DNA damage at the end of the study. However, with $p$ values of 0.175 for each, these did not attain statistical significance. 
There were no significant relationships between C-reactive protein, PSA and DNA damage.A non-significant trend towards a correlation between $\mathrm{C}$-reactive protein and peroxide-induced DNA damage was observed ( $p=0.156$ and $p=0.223$ at baseline and three months, respectively).

\section{Discussion}

The primary goal of this pilot study was to establish both feasibility and likelihood of benefit, as determined by a reduction in inflammation and DNA damage, for New Zealand men with prostate cancer following a modified Mediterranean diet. We sought to enrol men with untreated prostate cancer; however, due to low numbers of volunteers, men with low Gleason $(3+3$ or $3+$ 4) who had previously had treatment were included. It was anticipated that as our subjects had volunteered to participate in this intervention, they would be motivated, and thus amenable to changes that might be seen as advantageous in delaying disease progression. This was observed, and is consistent with what has been previously demonstrated in regards to cancer, motivation and dietary changes (Allen et al., 2008; Avery et al., 2013). It was anticipated that the dietary intervention would have demonstrable effects on DNA damage,PSA and C-reactive protein.

Adherence to a low inflammatory diet such as that used in this study may help to mitigate inflammation-associated increases in oxidative stress, genomic instability and damage to DNA (Kundu \& Surh, 2012).

Inflammation was evaluated by measuring C-reactive protein,a non-specific acute phase protein that serves as a surrogate for interleukin 6 , an inflammatory cytokine associated with angiogenesis, tumour growth and metastases. Within 6 hours of an inflammatory assault, Creactive protein increases. Constant levels are maintained commensurate with inflammatory processes and rapid clearance occurs when the stimulus is removed (Pepys \& Hirschfield, 2003). No change in C-reactive protein was observed in our cohort afterthree months of the dietary intervention, which is in contrast to other studies using a similar dietary regimen (Marlow et al., 2013; Ellett et al., 2013). Noteworthy in this regard is that baseline C-reactive protein in this group was low, with $95 \%$ of the cohort within the normal range of $<5 \mathrm{mg} / \mathrm{L}$, leaving little room for improvement. An inverse association between C-reactive protein and physical activity levels that was noted at the outset of this study was not evident at study end. Medication did not change in the group, with the exception of one participant who ceased taking non-steroidal antiinflammatory drugs during the study period. There was no resultant increase in C-reactive protein in this participant.

The effect of excess adiposity is an important consideration on the results seen. Obesity is a chronic, low-grade inflammatory state, which has been associated with both incidence and progression of prostate cancer (Ho et al., 2012). It was expected that study participants,four of whom were obese at the beginning of the study, might lose weight by following the dietary recommendations, (Martinez-Gonzalez et al., 2012). This did occur(mean weight loss $2.3 \mathrm{~kg}$ ), 
272 and while desirable in overweight men, may have masked anti-inflammatory attributes of the 273 diet. When stored adipose tissue is catabolised, the pro-inflammatory omega-6 fatty acid, 274 arachidonic acid, tends to be liberated (Phinney et al., 1991). Thus true benefit in terms of 275 lowering of inflammation might be better observed once body weight has stabilised. This would be best assessed following a longer intervention. No significant associations between body weight, BMI (or changes thereof) and DNA damage were noted in this study.C-reactive protein responds to a number of factors. Participants were not evaluated for injury or opportunistic infection at either the beginning or end of the study. While men retrospectively reported that they were "well" at the time of both blood draws, minor injuries or low-grade infections have the potential to increase acute phase inflammatory markers, C-reactive protein included. Similarly, study participants were not assessed for other factors that might impact C-reactive protein, such as sleep disturbances (Meier-Ewert et al., 2004)and food intake the day of sample collection(Margioris, 2009; Farnetti et al., 2011).

Levels of PSA were largely unchanged over the course of the study. However, PSA was below the level of detection in the majority of study participants, asis associated with successful treatment of prostate cancer. The lack of change in PSA, particularly in those men who had not undergone treatment for prostate cancer $(n=6)$, may indicate benefit in terms of PSA doubling time. While this is best evaluated over a longer period of time, mitigation of PSA increases have been demonstrated after 3 months of a dietary shift towards a more plant-based pattern (Saxe et al., 2008).

There are many individual components of the Mediterranean diet that have been studied in regards to their effect on a number of health outcomes. The health advantages of a diet that is high in fruit and vegetables, ostensibly due to the diversity of nutrients, with high levels of antioxidants and fibre associated with such dietary patterns is generally accepted.Indeed, lower levels of inflammation and increases in antioxidants have been correlated to fruit and vegetable intake (Root et al., 2012).While not all studies concur (Ambrosini et al., 2007; Boffetta et al., 2010), there is evidence suggesting benefit from vegetable and fruit intake in regards to prostate cancer (Riso et al., 1999; Hardin, Cheng \& Witte, 2011; Shahar et al., 2011).

The main benefit (weight loss aside) associated with this dietary intervention was reduction in DNA damage after three months, when compared to baseline data. This outcome was inversely associated with dietary adherence $(p=0.013)$.

Three months is considered sufficient time to determine the impact of diet on DNA repair in lymphocytes.As part of the circulatory system lymphocytes are constantly exposed to the positive and negative effects of diet and lifestyle.Therefore, they are an ideal target cell to assess the nutritional or chemical effect on DNA damage, regardless of their age.Other studies have

307 demonstrated the effect of dietary on DNA repair in lymphocytes in as little as 21 (Riso et al., 308 1999)and 24 days(Guarnieri et al., 2008). 
DNA damage has been positively associated with prostate cancer risk(Lockett et al., 2006),

310 hence increased DNA protection and repair is a highly desirable outcome, further supporting the

311 benefit of a diet high in antioxidants and low in saturated fat. Specific foods and nutrients,

312 particularly antioxidants and polyphenol compounds, can positively affect DNA repair(Duthie et

313 al., 1996; Giovannelli et al., 2002; Machowetz et al., 2007; Guarnieri et al., 2008). For example,

314 consumption of green tea (Kanwal et al., 2014), broccoli (Riso et al., 2010) and vitamin C

315 intake(Fraga et al., 1991) have been associated with increased DNA repair in previous studies,

316 while increases in DNA damage have been attributed to oxidative stress (Freitas et al., 2012;

317 Kundu \& Surh, 2012) and peroxidation of fatty acids (Gropper, Stepnick \& Smith, 2013). The

318 benefit of a Mediterranean diet on markers of DNA damage has been reported in women with the

319 metabolic syndrome (Mitjavila et al., 2013). As far as the authors are aware, this has not

320 previously been reported in men with prostate cancer.

321 Diet is a complex interaction of a wide range of foods and numerous individual compounds.

322 Genetic and epigenetic modifications can be affected by dietary phytonutrients, which modulate

323 DNA methylation and may induce or enhance DNA repair, the isolation of these compounds is a

324 commonly used, but reductionist approach, to nutritional research. In this study, dietary

325 adherence scores informed a comparison of the adoption of the diet as a whole, as well as the

326 integration of various aspects of it. The aspects of this diet that study participants found the most

327 acceptable were the incorporation of whole grains, olive oil, pomegranate juice, substitution of

328 red meat for chicken, and reducing consumption of sweetened beverages. Each of these achieved

$329>85 \%$ compliance overall. On the other hand, the least embraced components were inclusion of

330 sofrito, green tea, vegetables, broccoli, and adoption of recommended guidelines for alcohol (in

331 particular red wine). While compliance on these latter items was less than $60 \%$, changes in most

332 did reach statistical significance (Tables 4, 6and7).

333 It is apparent from the inverse association of adherence to the recommended diet with DNA

334 damage that this overall dietary pattern could be of benefit for men with prostate cancer. While

335 the possibility exists that reduced damage to DNA may be attributable to other characteristics of

336 this cohort, no parameter reported here suggests that this was the case. Other factors associated

337 with the Mediterranean diet, when compared to a typical western diet, include alterations in the

338 type of dietary fat and resultant changes in blood fatty acids. Such changes did occur in this

339 study, as is evident by the decrease in energy from saturated fat (Figure 2). Relationships

340 between DNA damage, dietary fats and blood fatty acids are explored elsewhere (Bishop et al.,

341 2015).

342 An inquiry into relationships between individual food items and the benefits seen on this diet

343 aids in justification of continued inclusion or otherwise in future studies. Such data is particularly

344 useful when recommending the incorporation of foods that may be considered unusual and to

345 support the development of strategies to aid increased compliance with less accepted

346 recommendations. 
While participants indicated that they were more inclined to choose chicken over red meat, overall complicity to the criteria for restriction of red meat consumption (to less than once weekly) did not indicate that this had actually occurred. In general, New Zealand consumption of beef and lamb is high (FAO, 2013), which is reflected in the baseline data. At the beginning of the study participants were consuming almost 4 servings of red and/or processed meat per week.Hence, while the reduction noted was significant $(p<0.001)$, intake was still higher than requested, suggesting that minimising red meat was a difficult change for participants to make.This may have been caused or compounded by the fact that this study was conducted over the summer period.The New Zealand summer coincides with the festive season, during which barbeques, as social events, are a common aspect of the culture.Thus avoidance of red meat may have been challenging for some participants.If indeed this was a major factor, it also raises the possibility that consumption of pro-carcinogenic heterocyclic amines, as is associated with meat cooked at high temperatures (Norrish et al., 1999), may have negated some of the benefits of the overall diet.

Green tea was not well accepted, with palatability being the reported obstacle. Nevertheless, green tea intake was associated with significant reduction in DNA damage $(p=0.002)$. This is in alignment with the remarkable antioxidant and anti-inflammatory properties associated with green tea, which contribute to its effect on DNA methylation (Julie \& Tim, 2012). Green tea consumption was reported by $25 \%$ of participants at baseline and $60 \%$ at study end. However, less than half were consuming the recommended intake of 2 cups daily. This relatively low uptake, but notable benefit, suggests that the incorporation of a beneficial dietary component may result in substantial gains, even if target levels are not attained.

No associations were noted for broccoli intake, which is in contrast to other reports (Latté, Appel \& Lampen, 2011; Ferguson \& Schlothauer, 2012). However, the inverse correlation noted between folate intake and DNA damage is consistent with current understanding of the role of folate in DNA methylation (Gropper, Stepnick \& Smith, 2013), and concurs with a recent study in which folate's role in DNA stability was demonstrated (Ong, Moreno \& Ross, 2011). In the current study, folate intake was calculated from diet diaries, and broccoli intake was determined from an adherence questionnaire, which was not sensitive to other sources of either folate or other cruciferous vegetables.

The role of vitamin $\mathrm{C}$ in regards to cancer is conflicting (Fraga et al., 1991; Herbert et al., 2006) making the finding of this study difficult to compare with other research. A dose-response relationship has been observed in regards to protection from DNA damage, with increasing vitamin C benefiting those with baseline low levels (Herbert et al., 2006; Freitas et al., 2012). In our study a significant inverse association was apparent between vitamin $\mathrm{C}$ intake and DNA damage ( $p=0.007$ ) at study end. Dietary vitamin $\mathrm{C}$ in the cohort was not low (Table 6). Examination of the data indicated that the source of this water soluble antioxidant shifted from fruit at baseline to vegetables at the end of the study.However, overall vegetable intake did not 
385

386

387

388

389

390

391

392

393

394

395

396

397

398

399

400

401

402

403

404

405

406

407

408

409

410

411

412

413

414

415

416

417

418

419

420

change.Furthermore, vegetables are more likely to be consumed cooked, which reduces vitamin C content(Gropper, Stepnick \& Smith, 2013).Together, this suggests that vitamin C was not solely associated with the effect noted, but rather, that a nutrient-nutrient interaction, such as with vitamin $\mathrm{E}$, may have occurred.Vitamin $\mathrm{E}$ intake increased over the course of the study ( $p=0.005$ ) (Table 6).This is congruent with current understanding of the synergistic relationship that exists between these two antioxidant vitamins (Gropper, Stepnick \& Smith, 2013). A large prospective study by Wrightet al.(Wright et al., 2007) suggested that dietary (but not supplemental) vitamin E may be an important nutrient in reducing the risk of advanced prostate cancer.

Diet is a complex interaction of phytonutrients and it is an accumulative, and/or synergistic effect of these that confers overall benefit.In other words, overall dietary patterns are possibly more important than individual components - a concept that has been proposed elsewhere (Viscogliosi et al., 2013).

From the results, it appears that the adoption of such a dietary pattern is feasible in motivated men. Not only were the changes, for the most part, embraced, but feedback from individual participants was encouragingly positive. While not part of the study design, at the end of the study and 3 months later, informal feedback was gathered from the participants. The information provided indicated that participants were heartened by their weight loss and the majority continued with the new diet. Study participants also reported improvements in overall energy and well-being, as well as positive effects on a range of other factors, including serum cholesterol, arthritic pain, and nocturia. Formal collection and evaluation of such data in future studies would contribute to strategies for supporting dietary change in men with prostate cancer.

The ethnic homogeneity of the group in the current study meant that the influence of variances in genetic expression was reduced. However, a number of other confounders, including genetic influences, were not controlled for as this would have rendered the group too small for meaningful analysis. The authors recognise the importance of gene-diet interactions and acknowledge that any testing related to genetic expression requires a larger study to demonstrate relevance. Despite the fact that this was a small feasibility study, positive outcomes were noted within a short time frame. In order to apply the findings to a general population, it is necessary to confirm the results with a largercohort. Such a study would allow stratification to control for a variety of confounding factors, such asadiposity, baseline dietary patterns, co-morbidities and lifestyle habits. The inclusion of a control group of men without prostate cancer would also be advantageous.

\section{Conclusions}

We demonstrated that dietary change towards a Mediterranean-style pattern is both achievable and beneficial for men with prostate cancer in New Zealand, albeit in a small and motivated 
group. While there have been numerous studies evaluating the impact of a Mediterranean diet on clinical indicators of disease (Giovannelli et al., 2002; Menendez \& Lupu, 2006; Fernández-Real et al., 2012; Kontogianni et al., 2012; Marlow et al., 2013; Mitjavila et al., 2013; Viscogliosi et al., 2013; Ellett et al., 2013) including prostate cancer(Ferrís-Tortajada et al., 2012; Kenfield et al., 2014), we believe this is the first time such a study has been conducted in regards to prostate cancer in New Zealand.This pilotstudy shows that a holistic approach to diet may contribute to modulation of DNA damage in spite of low baseline levels of inflammation. This is quite possibly due to an undeterminable synergistic effect of dietary components and associated phytonutrients.

Reduction in DNA damage was significantly associated with overall conformity to the general dietary pattern as well as intake of green tea, legumes, dietary vitamin $\mathrm{C}$ and folate. While no effect on inflammatory markers was demonstrated, baseline inflammation in this small cohort was low. Nonetheless, the results obtained add weight to the notion that a low-inflammatory, high antioxidant diet may be of benefit for men with prostate cancer.

Certain aspects of the diet were more acceptable to participants than others. An exploration of the challenges faced in integration of specific dietary components would inform strategies to encourage ongoing compliance, and ultimately, long-term benefit for men with prostate cancer, including those with more advanced disease.

\section{Acknowledgments}

We would like to thank our New Zealand sponsors, Oil Seed Extractions Ltd., Aoraki Smokehouse Salmon, Life Juices (New Zealand) Ltd., Delmaine Fine Foods.

With thanks to Shuotun Zhu, who conducted the phlebotomy, and AmaliniJesuthasan, who processed the laboratory samples.

Our gratitude is also extended to the men that committed themselves to this project, and their families.

\section{Author Contributions}

KSB planned and initiated the study. SE and KSB carried out the study, planned, and edited the manuscript.SE carried out the Comet assays and wrote the manuscript.SE and NK interpreted the resultsand edited drafts of the manuscript.DYH carried out the statistical analysis.LRFedited drafts of the manuscript.

\section{Conflicts of Interest}

The authors declare no conflict of interest. Companies who donated food items for the study were not involved (financially or otherwise) in the study design, approval, writing or publication of the manuscript. 


\section{References}

Allen NE, Key TJ, Appleby PN, Travis RC, Roddam AW, Tjonneland A, Johnsen NF, Overvad K, Linseisen J, Rohrmann S, Boeing H, Pischon T, Bueno-de-Mesquita HB, Kiemeney L, Tagliabue G, Palli D, Vineis P, Tumino R, Trichopoulou A, Kassapa C, Trichopoulos D, Ardanaz E, Larranaga N, Tormo MJ, Gonzalez CA, Quiros JR, Sanchez MJ, Bingham S, Khaw KT, Manjer J, Berglund G, Stattin P, Hallmans G, Slimani N, Ferrari P, Rinaldi S, Riboli E. 2008. Animal foods, protein, calcium and prostate cancer risk: the European Prospective Investigation into Cancer and Nutrition. British Journal of Cancer 98:15741581.

Ambrosini GL, de Klerk NH, Fritschi L, Mackerras D, Musk B. 2007. Fruit, vegetable, vitamin A intakes, and prostate cancer risk. Prostate Cancer and Prostatic Diseases 11:61-66.

Ambrosini GL, Fritschi L, de Klerk NH, Mackerras D, Leavy J. 2008. Dietary patterns identified using factor analysis and prostate cancer risk: a case control study in Western Australia. Ann Epidemiol 18:364-370.

Arsova-Sarafinovska Z, Eken A, Matevska N, Erdem O, Sayal A, Savaser A, Banev S, Petrovski D, Dzikova S, Georgiev V, Sikole A, Özgök Y, Suturkova L, Dimovski AJ, Aydin A. 2009. Increased oxidative/nitrosative stress and decreased antioxidant enzyme activities in prostate cancer. Clinical Biochemistry 42:1228-1235.

Avery KN, Donovan JL, Gilbert R, Davis M, Emmett P, Down L, Oliver S, Neal DE, Hamdy FC, Lane JA. 2013. Men with prostate cancer make positive dietary changes following diagnosis and treatment. Cancer Causes Control 24:1119-1128.

Baade PD, Youlden DR, Krnjacki LJ. 2009. International epidemiology of prostate cancer: geographical distribution and secular trends. Molecular Nutrition \& Food Research 53:171184.

Bishop KS, Erdrich S, Karunasinghe N, Han DY, Zhu S, Jesuthasan A, Ferguson LR, Jesuthasan, Amalini Ferguson LR. 2015. An investigation into the association between DNA damage and dietary fatty acids in men with prostate cancer. Nutrients 7:405-22.

Boffetta P, Couto E, Wichmann J, Ferrari P, Trichopoulos D, Bueno-de-Mesquita HB, van Duijnhoven FJB, Büchner FL, Key T, Boeing H, Nöthlings U, Linseisen J, Gonzalez CA, Overvad K, Nielsen MRS, Tjønneland A, Olsen A, Clavel-Chapelon F, Boutron-Ruault MC, Morois S, Lagiou P, Naska A, Benetou V, Kaaks R, Rohrmann S, Panico S, Sieri S, Vineis P, Palli D, van Gils CH, Peeters PH, Lund E, Brustad M, Engeset D, Huerta JM, Rodríguez L, Sánchez M-J, Dorronsoro M, Barricarte A, Hallmans G, Johansson I, Manjer J, Sonestedt E, Allen NE, Bingham S, Khaw K-T, Slimani N, Jenab M, Mouw T, Norat T, Riboli E, Trichopoulou A. 2010. Fruit and vegetable intake and overall cancer risk in the European Prospective Investigation into Cancer and Nutrition (EPIC). Journal of the National Cancer Institute 102:529-537. 
492

493

Bosire C, Stampfer MJ, Subar AF, Park Y, Kirkpatrick SI, Chiuve SE, Hollenbeck AR, Reedy J. 2013. Index-based dietary patterns and the risk of prostate cancer in the NIH-AARP diet and health study. American Journal of Epidemiology 177:504-513.

Brasky TM, Darke AK, Song X, Tangen CM, Goodman PJ, Thompson IM, Meyskens FL, Goodman GE, Minasian LM, Parnes HL, Klein EA, Kristal AR. 2013. Plasma phospholipid fatty acids and prostate cancer risk in the SELECT trial. Journal of the National Cancer Institute.

Brawer MK. 2005. Prostatic intraepithelial neoplasia: an overview. Reviews in Urology 7 Suppl 3:S11-8.

Center MM, Jemal A, Lortet-Tieulent J, Ward E, Ferlay J, Brawley O, Bray F. 2012. International variation in prostate cancer incidence and mortality rates. European Urology 61:1079-1092.

Chan JM, Stampfer MJ, Ma J, Gann P, Gaziano JM, Pollak M, Giovannucci E. 2002. Insulin-like growth factor-I (IGF-I) and IGF-binding protein-3 as predictors of advanced-stage prostate cancer. Journal of the National Cancer Institute 94:1099-1106.

Chan R, Lok K, Woo J. 2009. Prostate cancer and vegetable consumption. Molecular Nutrition \& Food Research 53:201-216.

Chavarro JE, Stampfer MJ, Hall MN, Sesso HD, Ma J. 2008. A 22-y prospective study of fish intake in relation to prostate cancer incidence and mortality. The American Journal of Clinical Nutrition 88:1297-1303.

Couto E, Boffetta P, Lagiou P, Ferrari P, Buckland G, Overvad K, Dahm CC, Tjonneland A, Olsen A, Clavel-Chapelon F, Boutron-Ruault MC, Cottet V, Trichopoulos D, Naska A, Benetou V, Kaaks R, Rohrmann S, Boeing H, von Ruesten A, Panico S, Pala V, Vineis P, Palli D, Tumino R, May A, Peeters PH, Bueno-de-Mesquita HB, Buchner FL, Lund E, Skeie G, Engeset D, Gonzalez CA, Navarro C, Rodriguez L, Sanchez MJ, Amiano P, Barricarte A, Hallmans G, Johansson I, Manjer J, Wirfart E, Allen NE, Crowe F, Khaw KT, Wareham N, Moskal A, Slimani N, Jenab M, Romaguera D, Mouw T, Norat T, Riboli E, Trichopoulou A. 2011. Mediterranean dietary pattern and cancer risk in the EPIC cohort. British Journal of Cancer 104:1493-1499.

Du GJ, Zhang Z, Wen XD, Yu C, Calway T, Yuan CS, Wang CZ. 2012. Epigallocatechin gallate (EGCG) is the most effective cancer chemopreventive polyphenol in green tea. Nutrients 4:1679-1691.

Duthie SJ, Ma A, Ross MA, Collins AR. 1996. Antioxidant supplementation decreases oxidative DNA damage in human lymphocytes. Cancer Research 56:1291-1295. 
Ellett S, Ferguson I, Zhu S, Karunasinghe N, Marlow G, Hurley D, Lam W, Han D, Ferguson L. 2013. Foodomics to study efficacy of human dietary interventions. In: Nutrigenomics and Nutrigenetics in Functional Foods and Personalized Nutrition. CRC Press, 269-280.

FAO. 2013. FAOSTAT. FAO Statistics Division 2013: Food and Agriculture Organisation of the United Nations.

Farnetti S, Malandrino N, Luciani D, Gasbarrini G, Capristo E. 2011. Food fried in extra-virgin olive oil improves postprandial insulin response in obese, insulin-resistant women. $J$ Med Food 14:316-321.

Ferguson LR, Han DY, Fraser AG, Huebner C, Lam WJ, Morgan AR, Duan H, Karunasinghe N. 2010. Genetic factors in chronic inflammation: single nucleotide polymorphisms in the STAT-JAK pathway, susceptibility to DNA damage and Crohn's disease in a New Zealand population. Mutation Research 690:108-15.

Ferguson LR, Schlothauer RC. 2012. The potential role of nutritional genomics tools in validating high health foods for cancer control: Broccoli as example. Molecular Nutrition and Food Research 56:126-146.

Ferlay J, Soerjomataram I, Ervik M, Dikshit R, Eser S, Mathers C, Rebelo M, Parkin DM, Forman D, Bray F. 2012. GLOBOCAN 2012 v1.0. Cancer incidence and mortality worldwide. IARC CancerBase No. 11 [In.

Fernández-Real JM, Bulló M, Moreno-Navarrete JM, Ricart W, Ros E, Estruch R, Salas-Salvadó J. 2012. A Mediterranean diet enriched with olive oil is associated with higher serum total osteocalcin levels in elderly men at high cardiovascular risk. The Journal of Clinical Endocrinology \& Metabolism 97:3792-3798.

Ferrís-Tortajada J, Berbel-Tornero O, García-Castell J, Ortega-García JA, López-Andreu JA. 2012. Dietetic factors associated with prostate cancer. Protective effects of Mediterranean diet. Actas Urológicas Españolas (English Edition) 36:239-245.

Fraga CG, Motchnik PA, Shigenaga MK, Helbock HJ, Jacob RA, Ames BN. 1991. Ascorbic acid protects against endogenous oxidative DNA damage in human sperm. Proceedings of the National Academy of Sciences of the United States of America 88:11003-11006.

Freitas M, Baldeiras I, Proenca T, Alves V, Mota-Pinto A, Sarmento-Ribeiro A. 2012. Oxidative stress adaptation in aggressive prostate cancer may be counteracted by the reduction of glutathione reductase. FEBS Open Bio 2:119-128.

Ganmaa D, Li X-M, Wang J, Qin L-Q, Wang P-Y, Sato A. 2002. Incidence and mortality of testicular and prostatic cancers in relation to world dietary practices. International Journal of Cancer 98:262-267. 
560

Gao X, LaValley MP, Tucker KL. 2005. Prospective studies of dairy product and calcium intakes and prostate cancer risk: a meta-analysis. J Natl Cancer Inst 97:1768-1777.

Gil MI, Tomas-Barberan FA, Hess-Pierce B, Holcroft DM, Kader AA. 2000. Antioxidant activity of pomegranate juice and its relationship with phenolic composition and processing. Journal of Agricultural and Food Chemistry 48:4581-4589.

Giovannelli L, Saieva C, Masala G, Testa G, Salvini S, Pitozzi V, Riboli E, Dolara P, Palli D. 2002. Nutritional and lifestyle determinants of DNA oxidative damage: a study in a Mediterranean population. Carcinogenesis 23:1483-1489.

Greene ER, Huang S, Serhan CN, Panigrahy D. 2011. Regulation of inflammation in cancer by eicosanoids. Prostaglandins \& Other Lipid Mediators 96:27-36.

Gropper S, Stepnick A, Smith JL. 2013. Advanced nutrition and human metabolism. Belmont, CA: Belmont, CA : Wadsworth/Cengage Learning c2013.

Guarnieri S, Loft S, Riso P, Porrini M, Risom L, Poulsen HE, Dragsted LO, Moller P. 2008. DNA repair phenotype and dietary antioxidant supplementation. Br J Nutr 99:1018-1024.

Gurel B, Lucia MS, Thompson IM, Goodman PJ, Tangen CM, Kristal AR, Parnes HL, Hoque A, Lippman SM, Sutcliffe S, Peskoe SB, Drake CG, Nelson WG, De Marzo AM, Platz EA. 2014. Chronic inflammation in benign prostate tissue is associated with high-grade prostate cancer in the placebo arm of the Prostate Cancer Prevention Trial. Cancer Epidemiology Biomarkers \& Prevention.

Hardin J, Cheng I, Witte JS. 2011. Impact of consumption of vegetable, fruit, grain, and high glycemic index foods on aggressive prostate cancer risk. Nutr Cancer 63:860-872.

Herbert KE, Fletcher S, Chauhan D, Ladapo A, Nirwan J, Munson S, Mistry P. 2006. Dietary supplementation with different vitamin $C$ doses: no effect on oxidative DNA damage in healthy people. Eur J Nutr 45:97-104.

Ho T, Gerber L, Aronson WJ, Terris MK, Presti JC, Kane CJ, Amling CL, Freedland SJ. 2012. Obesity, prostate-specific antigen nadir, and biochemical recurrence after radical prostatectomy: biology or technique? Results from the SEARCH database. Eur Urol 62:910-916.

Huffman KM, Samsa GP, Slentz CA, Duscha BD, Johnson JL, Bales CW, Tanner CJ, Houmard JA, Kraus WE. 2006. Response of high-sensitivity C-reactive protein to exercise training in an at-risk population. American Heart Journal 152:793-800.

Huncharek M, Muscat J, Kupelnick B. 2008. Dairy products, dietary calcium and vitamin D intake as risk factors for prostate cancer: a meta-analysis of 26,769 cases from 45 observational studies. Nutr Cancer 60:421-441. 
594

Il'yasova D, Colbert LH, Harris TB, Newman AB, Bauer DC, Satterfield S, Kritchevsky SB. 2005. Circulating levels of inflammatory markers and cancer risk in the health aging and body composition cohort. Cancer Epidemiology Biomarkers \& Prevention 14:2413-2418.

Jain S, Chakraborty G, Raja R, Kale S, Kundu GC. 2008. Prostaglandin E2 regulates tumor angiogenesis in prostate cancer. Cancer Research 68:7750-7759.

Joven J, Micol V, Segura-Carretero A, Alonso-Villaverde C, Menéndez JA, for the Bioactive Food Components Platform $\uparrow$. 2013. Polyphenols and the modulation of gene expression pathways: Can we eat our way out of the danger of chronic disease? Critical Reviews in Food Science and Nutrition 54:985-1001.

Julie MR, Tim DE. 2012. The cellular component of chronic inflammation. In: Chronic Inflammation. CRC Press, 21-34.

Kanwal R, Pandey M, Bhaskaran N, Maclennan GT, Fu P, Ponsky LE, Gupta S. 2014. Protection against oxidative DNA damage and stress in human prostate by glutathione S-transferase P1. Molecular Carcinogenesis 53:8-18.

Karunasinghe N, Ryan J, Tuckey J, Masters J, Jamieson M, Clarke LC, Marshall JR, Ferguson LR. 2004. DNA stability and serum selenium levels in a high-risk group for prostate cancer. Cancer Epidemiol. Biomarkers Prev. 13:391-397.

Karunasinghe N, Han DY, Goudie M, Zhu S, Bishop K, Wang A, Duan H, Lange K, Ko S, Medhora R, Kan ST, Masters J, Ferguson LR. 2012. Prostate disease risk factors among a New Zealand cohort. Journal of Nutrigenetics \& Nutrigenomics 5:339-351.

Kenfield SA, Dupre N, Richman EL, Stampfer MJ, Chan JM, Giovannucci EL. 2014. Mediterranean diet and prostate cancer risk and mortality in the Health Professionals Follow-up Study. Eur Urol 65:887-894.

Koh KA, Sesso HD, Paffenbarger Jr. RS, Lee IM. 2006. Dairy products, calcium and prostate cancer risk. British Journal of Cancer 95:1582-1585.

Kontogianni MD, Chrysohoou C, Panagiotakos DB, Tsetsekou E, Zeimbekis A, Pitsavos C, Stefanadis C. 2012. Adherence to the Mediterranean diet and serum uric acid: the ATTICA study. Scandinavian Journal of Rheumatology 41:442-449.

Koyama S, Cobb LJ, Mehta HH, Seeram NP, Heber D, Pantuck AJ, Cohen P. 2010. Pomegranate extract induces apoptosis in human prostate cancer cells by modulation of the IGF-IGFBP axis. Growth Hormone \& IGF Research 20:55-62.

Kundu JK, Surh Y-J. 2012. Emerging avenues linking inflammation and cancer. Free Radical Biology and Medicine 52:2013-2037. 
627

628

629

630

631

632

633

634

635

636

637

638

639

640

641

642

643

644

645

646

647

648

649

650

651

652

653

654

655

656

657

658

659

660

Kurahashi N, Sasazuki S, Iwasaki M, Inoue M, Tsugane S, Group JS. 2008. Green tea consumption and prostate cancer risk in Japanese men: a prospective study. American Journal of Epidemiology 167:71-77.

Landberg R, Andersson S-O, Zhang J-X, Johansson J-E, Stenman U-H, Adlercreutz H, KamalEldin A, Åman P, Hallmans G. 2010. Rye whole grain and bran intake compared with refined wheat decreases urinary C-peptide, plasma insulin, and prostate specific antigen in men with prostate cancer. The Journal of Nutrition 140:2180-2186.

Latté KP, Appel K-E, Lampen A. 2011. Health benefits and possible risks of broccoli - An overview. Food and Chemical Toxicology 49:3287-3309.

Lockett KL, Hall MC, Clark PE, Chuang SC, Robinson B, Lin HY, Su LJ, Hu JJ. 2006. DNA damage levels in prostate cancer cases and controls. Carcinogenesis 27:1187-1193.

Machowetz A, Poulsen HE, Gruendel S, Weimann A, Fito M, Marrugat J, de la Torre R, Salonen JT, Nyyssonen K, Mursu J, Nascetti S, Gaddi A, Kiesewetter H, Baumler H, Selmi H, Kaikkonen J, Zunft HJ, Covas MI, Koebnick C. 2007. Effect of olive oils on biomarkers of oxidative DNA stress in Northern and Southern Europeans. FASEB J 21:45-52.

Malcolm JB, Derweesh IH, Kincade MC, DiBlasio CJ, Lamar KD, Wake RW, Patterson AL. 2007. Osteoporosis and fractures after androgen deprivation initiation for prostate cancer. Can J Urol 14:3551-3559.

Margioris AN. 2009. Fatty acids and postprandial inflammation. Curr Opin Clin Nutr Metab Care 12:129-137.

Marlow G, Ellett S, Ferguson IR, Zhu S, Karunasinghe N, Jesuthasan AC, Han DY, Fraser AG, Ferguson LR. 2013. Transcriptomics to study the effect of a Mediterranean-inspired diet on inflammation in Crohn's disease patients. Human Genomics 7:24.

Martinez-Gonzalez MA, Garcia-Arellano A, Toledo E, Salas-Salvado J, Buil-Cosiales P, Corella D, Covas MI, Schroder H, Aros F, Gomez-Gracia E, Fiol M, Ruiz-Gutierrez V, Lapetra J, Lamuela-Raventos RM, Serra-Majem L, Pinto X, Munoz MA, Warnberg J, Ros E, Estruch R. 2012. A 14-item Mediterranean diet assessment tool and obesity indexes among highrisk subjects: the PREDIMED trial. PLoS ONE [Electronic Resource] 7:e43134.

McArdle PA, Qayyum T, McMillan DC. 2010. Systemic inflammatory response and survival in patients with localised prostate cancer: 10-year follow-up. Urologia Internationalis 84:435460 .

Meier-Ewert HK, Ridker PM, Rifai N, Regan MM, Price NJ, Dinges DF, Mullington JM. 2004. Effect of sleep loss on C-reactive protein, an inflammatory marker of cardiovascular risk. $J$ Am Coll Cardiol 43:678-683. 
661

662

663

664

665

666

667

668

669

670

671

672

673

674

675

676

677

678

679

680

681

682

683

684

685

686

687

688

689

690

691

692

693

694

695

Melnik BC, John SM, Schmitz G. 2011. Over-stimulation of insulin/IGF-1 signaling by western diet may promote diseases of civilization: lessons learnt from laron syndrome. Nutrition \& Metabolism 8:41.

Menendez JA, Lupu R. 2006. Mediterranean dietary traditions for the molecular treatment of human cancer: anti-oncogenic actions of the main olive oil's monounsaturated fatty acid oleic acid (18:1n-9). Current Pharmaceutical Biotechnology 7:495-502.

Mitjavila MT, Fandos M, Salas-Salvado J, Covas M-I, Borrego S, Estruch R, Lamuela-Raventos R, Corella D, Martinez-Gonzalez MA, Sanchez JM, Bullo M, Fito M, Tormos C, Cerda C, Casillas R, Moreno JJ, Iradi A, Zaragoza C, Chaves J, Saez GT. 2013. The Mediterranean diet improves the systemic lipid and DNA oxidative damage in metabolic syndrome individuals. A randomized, controlled, trial. Clinical Nutrition 32:172-178.

MOH. 2013. Cancer: New registrations and deaths 2010. Wellington: Ministry of Health (New Zealand).

Moreno DA, Carvajal M, López-Berenguer C, García-Viguera C. 2006. Chemical and biological characterisation of nutraceutical compounds of broccoli. Journal of Pharmaceutical and Biomedical Analysis 41:1508-1522.

Norrish AE, Ferguson LR, Knize MG, Felton JS, Sharpe SJ, Jackson RT. 1999. Heterocyclic amine content of cooked meat and risk of prostate cancer. J Natl Cancer Inst 91:2038-2044.

Ong TP, Moreno FS, Ross SA. 2011. Targeting the epigenome with bioactive food components for cancer prevention. Journal of Nutrigenetics \& Nutrigenomics 4:275-292.

Paller CJ, Ye X, Wozniak PJ, Gillespie BK, Sieber PR, Greengold RH, Stockton BR, Hertzman BL, Efros MD, Roper RP, Liker HR, Carducci MA. 2012. A randomized phase II study of pomegranate extract for men with rising PSA following initial therapy for localized prostate cancer. Prostate Cancer and Prostatic Diseases.

Pantuck AJ, Leppert JT, Zomorodian N, Aronson W, Hong J, Barnard RJ, Seeram N, Liker H, Wang H, Elashoff R, Heber D, Aviram M, Ignarro L, Belldegrun A. 2006. Phase II study of pomegranate juice for men with rising prostate-specific antigen following surgery or radiation for prostate cancer. Clinical Cancer Research 12:4018-4026.

Pantuck AJ, Zomorodian N, Rettig M, Aronson WJ, Heber D, Belldegrun AS. 2009. Long term follow up of phase 2 study of pomegranate juice for men with prostate cancer shows durable prolongation of PSA doubling time. The Journal of Urology 181:295.

Pepys MB, Hirschfield GM. 2003. C-reactive protein: a critical update. The Journal of Clinical Investigation 111:1805-12.

Pettersson A, Kasperzyk JL, Kenfield SA, Richman EL, Chan JM, Willett WC, Stampfer MJ, Mucci LA, Giovannucci EL. 2012. Milk and dairy consumption among men with prostate 
696

697

698

699

700

701

702

703

704

705

706

707

708

709

710

711

712

713

714

715

716

717

718

719

720

721

722

723

724

725

726

727

728

cancer and risk of metastases and prostate cancer death. Cancer Epidemiol Biomarkers Prev 21:428-436.

Phinney SD, Davis PG, Johnson SB, Holman RT. 1991. Obesity and weight loss alter serum polyunsaturated lipids in humans. Am J Clin Nutr 53:831-838.

Platz EA, De Marzo AM. 2004. Epidemiology of inflammation and prostate cancer. The Journal of Urology 171:S36-S40.

Qu Y, Oyan AM, Liu R, Hua Y, Zhang J, Hovland R, Popa M, Liu X, Brokstad KA, Simon R, Molven A, Lin B, Zhang WD, McCormack E, Kalland KH, Ke XS. 2013. Generation of prostate tumor-initiating cells is associated with elevation of reactive oxygen species and IL-6/STAT3 signaling. Cancer Research 73:7090-7100.

Riso P, Pinder A, Santangelo A, Porrini M. 1999. Does tomato consumption effectively increase the resistance of lymphocyte DNA to oxidative damage? The American Journal of Clinical Nutrition 69:712-718.

Riso P, Martini D, Møller P, Loft S, Bonacina G, Moro M, Porrini M. 2010. DNA damage and repair activity after broccoli intake in young healthy smokers. Mutagenesis 25:595-602.

Root MM, McGinn MC, Nieman DC, Henson DA, Heinz SA, Shanely RA, Knab AM, Jin F. 2012. Combined fruit and vegetable intake is correlated with improved inflammatory and oxidant status from a cross-sectional study in a community setting. Nutrients 4:29-41.

Rytter E, Vessby B, Asgard R, Johansson C, Sjodin A, Abramsson-Zetterberg L, Moller L, Basu S. 2009. Glycaemic status in relation to oxidative stress and inflammation in well-controlled type 2 diabetes subjects. Br J Nutr 101:1423-1426.

Saxe GA, Major JM, Westerberg L, Khandrika S, Downs TM. 2008. Biological mediators of effect of diet and stress reduction on prostate cancer. Integr Cancer Ther 7:130-138.

Shafique K, Proctor MJ, McMillan DC, Qureshi K, Leung H, Morrison DS. 2012. Systemic inflammation and survival of patients with prostate cancer: evidence from the Glasgow Inflammation Outcome Study. Prostate Cancer Prostatic Diseases 15:21-195.

Shahar S, Shafurah S, Hasan Shaari NS, Rajikan R, Rajab NF, Golkhalkhali B, Zainuddin ZM. 2011. Roles of diet, lifetime physical activity and oxidative DNA damage in the occurrence of prostate cancer among men in Klang Valley, Malaysia. Asian Pac J Cancer Prev 12:605611.

Shariat SF, Andrews B, Kattan MW, Kim J, Wheeler TM, Slawin KM. 2001. Plasma levels of interleukin- 6 and its soluble receptor are associated with prostate cancer progression and metastasis. Urology 58:1008-1015. 
729

730

731

732

733

734

735

736

737

738

739

740

741

742

743

744

745

746

747

748

749

750

751

752

753

754

755

756

757

758

759

760

761

762

763

764

Stark JR, Li H, Kraft P, Kurth T, Giovannucci EL, Stampfer MJ, Ma J, Mucci LA. 2009. Circulating prediagnostic interleukin- 6 and C-reactive protein and prostate cancer incidence and mortality. International Journal of Cancer 124:2683-2689.

Stott-Miller M, Neuhouser ML, Stanford JL. 2013. Consumption of deep-fried foods and risk of prostate cancer. The Prostate 73:960-9.

Terry P, Lichtenstein P, Feychting M, Ahlbom A, Wolk A. 2001. Fatty fish consumption and risk of prostate cancer. Lancet 357:1764-1766.

Torfadottir JE, Steingrimsdottir L, Mucci L, Aspelund T, Kasperzyk JL, Olafsson O, Fall K, Tryggvadottir L, Harris TB, Launer L, Jonsson E, Tulinius H, Stampfer M, Adami HO, Gudnason V, Valdimarsdottir UA. 2012. Milk intake in early life and risk of advanced prostate cancer. Am J Epidemiol 175:144-153.

Trichopoulou A, Orfanos P, Norat T, Bueno-de-Mesquita B, Ocke MC, Peeters PHM, van der Schouw YT, Boeing H, Hoffmann K, Boffetta P, Nagel G, Masala G, Krogh V, Panico S, Tumino R, Vineis P, Bamia C, Naska A, Benetou V, Ferrari P, Slimani N, Pera G, Martinez-Garcia C, Navarro C, Rodriguez-Barranco M, Dorronsoro M, Spencer EA, Key TJ, Bingham S, Khaw K-T, Kesse E, Clavel-Chapelon F, Boutron-Ruault M-C, Berglund G, Wirfalt E, Hallmans G, Johansson I, Tjonneland A, Olsen A, Overvad K, Hundborg HH, Riboli E, Trichopoulos D. 2005. Modified Mediterranean diet and survival: EPIC-elderly prospective cohort study. BMJ 330:991.

Tuck KL, Hayball PJ. 2002. Major phenolic compounds in olive oil: metabolism and health effects. The Journal of Nutritional Biochemistry 13:636-644.

Tymchuk CN, Tessler SB, Aronson WJ, Barnard RJ. 1998. Effects of diet and exercise on insulin, sex hormone-binding globulin, and prostate-specific antigen. Nutr Cancer 31:127131.

Urpi-Sarda M, Casas R, Chiva-Blanch G, Romero-Mamani ES, Valderas-Martinez P, Arranz S, Andres-Lacueva C, Llorach R, Medina-Remon A, Lamuela-Raventos RM, Estruch R. 2012. Virgin olive oil and nuts as key foods of the Mediterranean diet effects on inflammatory biomakers related to atherosclerosis. Pharmacol Res 65:577-583.

Viscogliosi G, Cipriani E, Liguori ML, Marigliano B, Saliola M, Ettorre E, Andreozzi P. 2013. Mediterranean dietary pattern adherence: associations with prediabetes, metabolic syndrome, and related microinflammation. Metab Syndr Relat Disord 11:210-216.

Waris G, Ahsan H. 2006. Reactive oxygen species: role in the development of cancer and various chronic conditions. Journal of Carcinogenesis 5:14.

Wright ME, Weinstein SJ, Lawson KA, Albanes D, Subar AF, Dixon LB, Mouw T, Schatzkin A, Leitzmann MF. 2007. Supplemental and dietary vitamin E intakes and risk of prostate cancer in a large prospective study. Cancer Epidemiology, Biomarkers \& Prevention : a 
765 publication of the American Association for Cancer Research, cosponsored by the

766 American Society of Preventive Oncology 16:1128-35.

767 Zheng J, Yang B, Huang T, Yu Y, Yang J, Li D. 2011. Green tea and black tea consumption and

768 prostate cancer risk: An exploratory meta-analysis of observational studies. Nutrition and

769 Cancer 63:663-672.

770 (C) 2014by the authors 
Figure 1 (on next page)

Factors involved in the pathogenesis of tumour development (Pantuck et al., 2006; Waris \& Ahsan, 2006). 
PeerJ Reviewing Manuscript

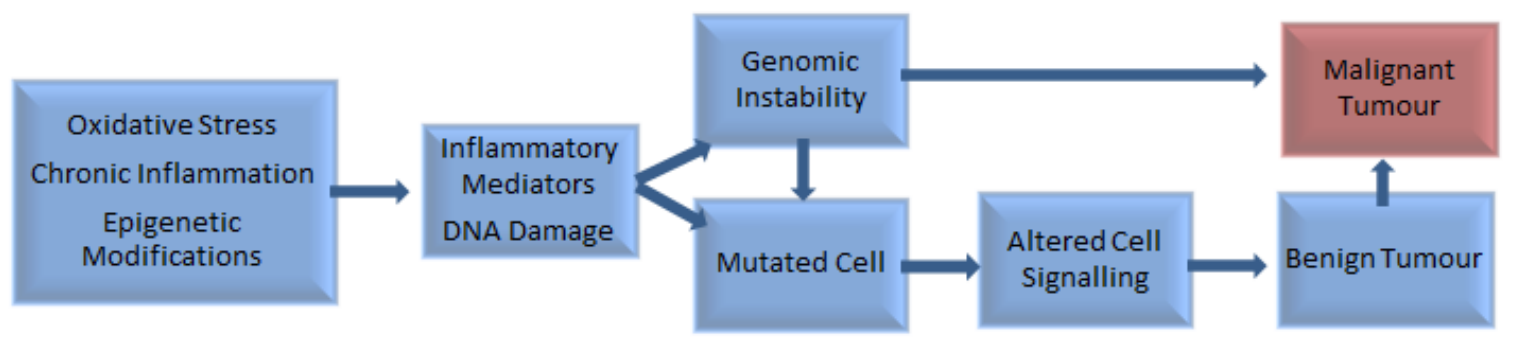


Table $\mathbf{1}$ (on next page)

A brief outline of food items/groups that study-participants were asked to consume or avoid.

*Unless contraindicated due to health problems, allergies or intolerances **Preferred items 
3 Table 1. A brief outline of food items/groups that study-participants were asked to consume or 4 avoid.

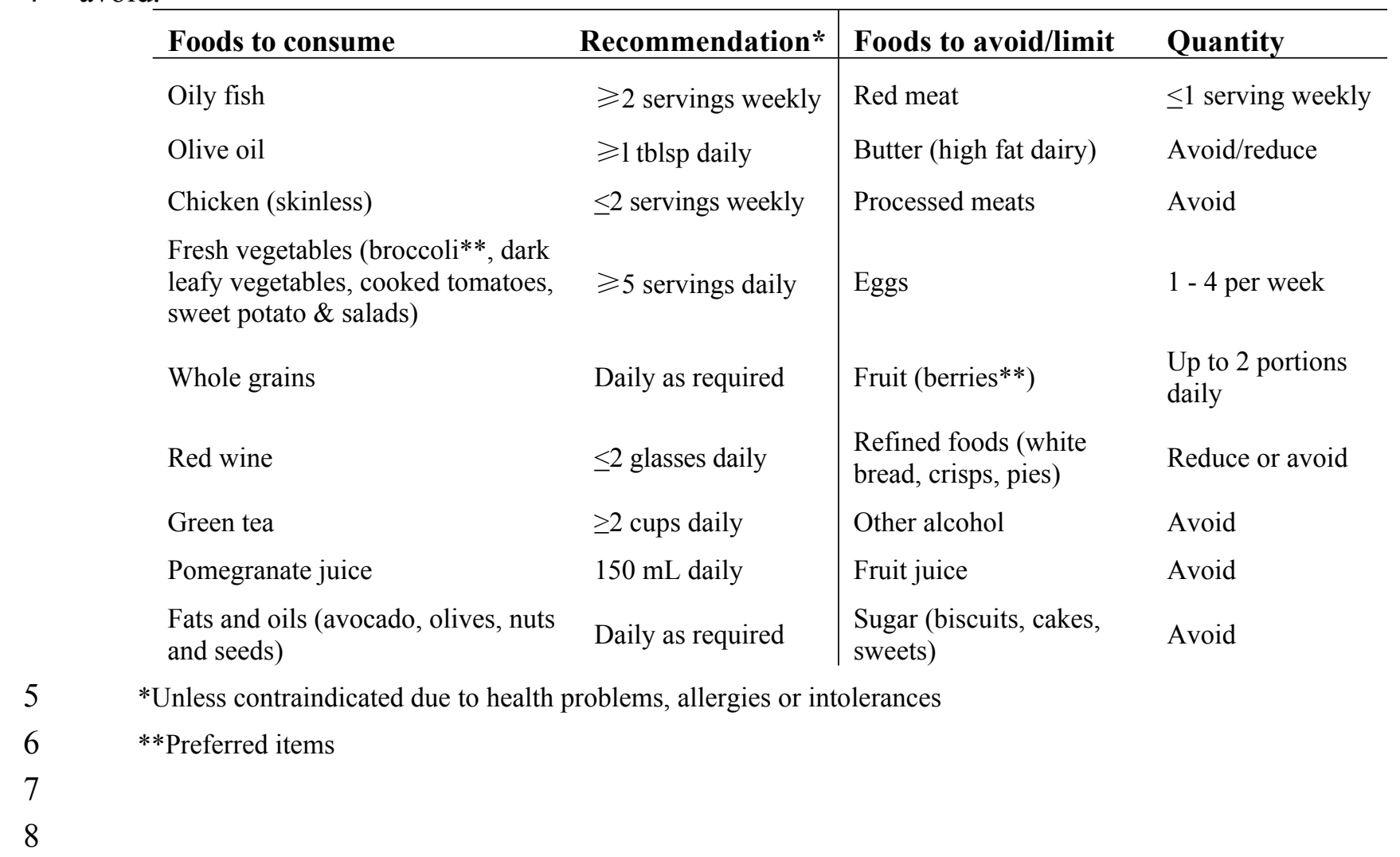


Table 2 (on next page)

Dietary Adherence Questionnaire

Adapted from Martinez-Gonzalez, M. A., Garcia-Arellano, A., Toledo, E., Salas-Salvado, J., BuilCosiales, P., Corella, D., . . Investigators, P. S. (2012). A 14-item Mediterranean diet assessment tool and obesity indexes among high-risk subjects: the PREDIMED trial. PLOS ONE [Electronic Resource], 7(8), e43134. (Martinez-Gonzalez et al., 2012) 


\section{Assessing Your "Mediterranean Diet"}

4 Please indicate your answers to the questions in the space provided.

\begin{tabular}{|c|c|c|}
\hline \multicolumn{2}{|c|}{ Question } & \multirow[t]{2}{*}{ Answer } \\
\hline 1. & Do you use olive oil as a culinary fat? & \\
\hline 2. & $\begin{array}{l}\text { How much olive oil do you use in a given day (including oil used for frying, salads, } \\
\text { out-of-house meals, etc.)? }\end{array}$ & \\
\hline \multirow[t]{2}{*}{3.} & \multirow{2}{*}{$\begin{array}{ll}\text { How many vegetable servings do you consume per day? } & \text { Cooked: } \\
\text { ( } 1 \text { serving }: 1 / 2 \text { cup cooked vegetables or } 1 \text { cup raw vegetables }) & \\
\text { [consider side-dishes as half a serving] } & \text { Raw / salad: }\end{array}$} & \\
\hline & & \\
\hline 4. & How many fruit units (including natural fruit juices) do you consume per day? & \\
\hline 5. & $\begin{array}{l}\text { How many servings of red meat, hamburger, or meat products (ham, sausage, etc.) } \\
\text { do you consume per week? ( } 1 \text { serving }: 100-150 \mathrm{~g})\end{array}$ & \\
\hline 6. & $\begin{array}{l}\text { How many servings of butter, margarine or cream do you consume per day? } \\
\text { (1 serving : } 12 \mathrm{~g} / \text { approx. } 2 \mathrm{tsp} \text { ) }\end{array}$ & \\
\hline 7. & How many sweet or carbonated beverages do you drink per day? & \\
\hline 8. & How much wine do you drink per week? & \\
\hline 9. & How many servings of legumes do you consume per week? ( 1 serving : $150 \mathrm{~g}$ ) & \\
\hline 10. & $\begin{array}{l}\text { How many servings of fish or shellfish do you consume per week? (1 serving : } 100 \text { - } \\
150 \mathrm{~g} \text { of fish, or } 200 \mathrm{~g} / 4-5 \text { units of shellfish) }\end{array}$ & \\
\hline 11. & $\begin{array}{l}\text { How many times per week do you consume sweets or pastries, such as cakes, } \\
\text { cookies, biscuits or custard? }\end{array}$ & \\
\hline 12. & $\begin{array}{l}\text { How many servings of nuts (including peanuts) do you consume per week? (1 } \\
\text { serving : } 30 \mathrm{~g} \text { ) }\end{array}$ & \\
\hline 13. & $\begin{array}{l}\text { Do you preferentially consume chicken, turkey or rabbit meat instead of veal, pork, } \\
\text { hamburger or sausage? }\end{array}$ & \\
\hline 14. & $\begin{array}{l}\text { How many times per week do you consume vegetables, pasta, rice or other dishes } \\
\text { seasoned with sofrito (sauce made with tomato and onion, leek or garlic and } \\
\text { simmered with olive oil)? }\end{array}$ & \\
\hline 15. & $\begin{array}{l}\text { How many servings of pomegranate fruit ( } 1 \text { serving : } 1 \text { piece }) \text {, pomegranate juice ( } 1 \\
\text { serving : } 200 \mathrm{~mL}) \text {, or of pomegranate molasses }\left(1 \text { serving }: 1 \frac{1}{2} \text { tblsp }\right) \text { do you have per } \\
\text { day? }\end{array}$ & \\
\hline 16. & $\begin{array}{l}\text { How much alcohol (other than wine) do you drink per week? (1 serving : } 1 \text { nip } \\
\text { spirits, } 300 \mathrm{~mL} \text { beer) }\end{array}$ & \\
\hline 17. & How many cups of green tea do you drink per day? & \\
\hline 18. & How many servings of broccoli do you consume per week? & \\
\hline 19. & $\begin{array}{l}\text { How many servings of dairy products do you have per week? (1 serving : } 30 \mathrm{~g} \\
\text { cheese, } 250 \mathrm{~mL} \text { milk, } 100 \mathrm{~mL} \text { yoghurt) }\end{array}$ & \\
\hline 20. & $\begin{array}{l}\text { Do you preferentially use wholegrain bread and crackers instead of white / refined } \\
\text { bread and crackers? }\end{array}$ & \\
\hline
\end{tabular}


5 Adapted from Martinez-Gonzalez, M. A., Garcia-Arellano, A., Toledo, E., Salas-Salvado, J., Buil-Cosiales, P., Corella, D., . . Investigators, P. S.

6 (2012). A 14-item Mediterranean diet assessment tool and obesity indexes among high-risk subjects: the PREDIMED trial. PLoS ONE [Electronic

7 Resource], 7(8), e43134. (Martinez-Gonzalez et al., 2012)

8 
Table 3 (on next page)

Characteristics of study participants at baseline. 
Table 3. Characteristics of study participants at baseline.

\begin{tabular}{|c|c|c|c|}
\hline Characteristic & $n$ & Characteristic & $n$ \\
\hline Age 52-74 Years & & BMI $23-33 \mathrm{~kg} / \mathrm{m}^{2}$ & \\
\hline $50-59$ & 3 & $\geq 20-\leq 25$ & 4 \\
\hline $60-69$ & 12 & $>25-\leq 30$ & 12 \\
\hline$>70$ & 5 & $>30$ & 4 \\
\hline Marital Status & & Family History of PCa & \\
\hline Married or with Partner & 17 & $1^{\circ}$ relative with $\mathrm{PCa}$ & 3 \\
\hline Single or Widowed & 3 & Other relative with $\mathrm{PCa}$ & 2 \\
\hline Ethnicity & & Gleason Score & \\
\hline Caucasian & 20 & $3+3$ & 14 \\
\hline Smoking Status & & $3+4$ & 6 \\
\hline Never & 7 & Time since diagnosis (years) & $1-10$ \\
\hline Former & 13 & Treatment type & \\
\hline Current & 0 & None & 6 \\
\hline Activity Level * & & Prostatectomy & 10 \\
\hline Heavy & 1 & Prostatectomy + Hormones + DxR & 1 \\
\hline Moderate & 2 & Prostatectomy + DxR & 1 \\
\hline Light-Moderate & 1 & Hormones + DxR & 1 \\
\hline Light & 5 & Brachytherapy & 1 \\
\hline Sedentary & 10 & Medication & \\
\hline Very Sedentary & 1 & Statins & 6 \\
\hline Alcohol Intake & & Aspirin & 5 \\
\hline Non-Drinkers & 4 & Diclofenac & 4 \\
\hline$\leq 2$ Standard Drinks Per Day & 10 & Anti-hypertensive & 4 \\
\hline$>2$ Standard Drinks Per Day & 6 & TNF-antagonist & 1 \\
\hline PSA (mean, $\mu \mathrm{g} / \mathrm{L}$ ) & 1.53 & Allopurinol & 1 \\
\hline CRP (mean, mg/L) & 1.55 & Other & 6 \\
\hline
\end{tabular}




\section{Table 4(on next page)}

Pooled dietary adherence scores from 20 participants at baseline and three months. A maximum of 1 point for each item per participant was possible. 20 points reflects complete adherence by the whole cohort.

* Half-points were allocated wherever a shift towards improved adherence of $\geq 30 \%$ was evident

tblsp, tablespoon; incl, including; excl, excluding. 
Table 4 Pooled dietary adherence scores from 20 participants at baseline and three months. A maximum of 1 point for each item per participant was possible. 20 points reflects complete adherence by the whole cohort.

\begin{tabular}{lllll}
\hline Dietary Component & $\begin{array}{l}\text { Criteria for } \\
\text { One Point }\end{array}$ & Baseline & $\begin{array}{l}\text { Three } \\
\text { Months } \\
*\end{array}$ & $\boldsymbol{p}$ \\
\hline 1. Olive Oil As Culinary Fat & Yes & 13 & 20.0 & $\mathbf{0 . 0 2 1}$ \\
2. Olive Oil Used Daily & $\geq 1$ tblsp & 8 & 17.0 & $\mathbf{0 . 0 0 3}$ \\
3. Servings of Vegetables/Day & $\geq 4$ & 6 & 8.5 & 0.0563 \\
4. Servings of Fruit/Day (Incl. Pomegranate) & $\leq 2$ & 9 & 11.5 & 0.449 \\
5. Servings of Red Meat, Hamburger, etc./Week & $<1$ & 1 & 11.5 & $<\mathbf{0 . 0 0 1}$ \\
6. Servings of Butter, Margarine or Cream/Day & $<1$ & 3 & 14.5 & $<\mathbf{0 . 0 0 1}$ \\
7. Sweet or Carbonated Beverages/Day & $<1$ & 16 & 20.0 & 0.083 \\
8. Wine Consumed/Week (Glasses) & $7-14$ & 5 & 5.5 & 0.577 \\
9. Servings of Legumes/Week & $\geq 5$ & 6 & 16.0 & $<\mathbf{0 . 0 0 1}$ \\
10. Servings of Fish or Shellfish/Week & $\geq 3$ & 4 & 14.0 & $<\mathbf{0 . 0 0 1}$ \\
11. Sweets or Pastries/Week & $<3$ & 7 & 16.0 & $<\mathbf{0 . 0 0 1}$ \\
12. Servings of Nuts/Week & $\geq 5$ & 5 & 16.0 & $<\mathbf{0 . 0 0 1}$ \\
13. Preference for Chicken, etc. & Yes & 7 & 18.0 & $<\mathbf{0 . 0 0 1}$ \\
14. Use of Sofrito Sauce/Week & $\geq 2$ & 6 & 9.5 & 0.297 \\
15. Servings of Pomegranate/Day & $\geq 1$ & 1 & 19.5 & $<\mathbf{0 . 0 0 1}$ \\
16. Units of Other Alcohol (Excl. Wine)/Week & 0 & 5 & 7.5 & $\mathbf{0 . 0 2 5}$ \\
17. Cups of Green Tea/Day & $\geq 2$ & 2 & 9.0 & $\mathbf{0 . 0 0 8}$ \\
18. Servings of Broccoli/Week & $\geq 5$ & 0 & 6.5 & $\mathbf{0 . 0 0 4}$ \\
19. Servings of Dairy Products/Week & $\leq 5$ & 5 & 13.0 & $\mathbf{0 . 0 0 3}$ \\
20. Use of Whole Grains & Yes & 16 & 20.0 & $\mathbf{0 . 0 4 2}$ \\
\hline
\end{tabular}

* Half-points were allocated wherever a shift towards improved adherence of $\geq 30 \%$ was evident; tblsp, tablespoon; incl, including; excl, excluding. 
Table 5(on next page)

Comparison of estimated energy requirements and reported energy intake. 
2 Table 5. Comparison of estimated energy requirements and reported energy intake.

\begin{tabular}{lllll}
\hline Energy Intake & $\begin{array}{l}\text { Baseline } \\
\text { Mean (SE) }\end{array}$ & $\begin{array}{l}\text { Three Months } \\
\text { Mean (SE) }\end{array}$ & $\begin{array}{l}\text { Mean Difference } \\
\text { (95\% CI) }\end{array}$ & $\begin{array}{l}\boldsymbol{p} \text { - } \\
\text { value }\end{array}$ \\
\hline $\begin{array}{l}\text { EER /kJ } \\
\text { Reported energy intake } \\
\text { /kJ }\end{array}$ & $10,675.6(305.43)$ & $10,476.05(292.00)$ & $-199.6(-427.40-28.27)$ & 0.083 \\
\hline
\end{tabular}

3 EER, estimated energy requirement; kJ, kilojoules; SE, standard error; CI, confidence interval.

4 
Figure 2 (on next page)

Change in sources of energy expressed as \% of total energy intake at baseline and three months.

SatFat $=$ saturated fat; $* p<0.001$. 
PeerJ Reviewing Manuscript

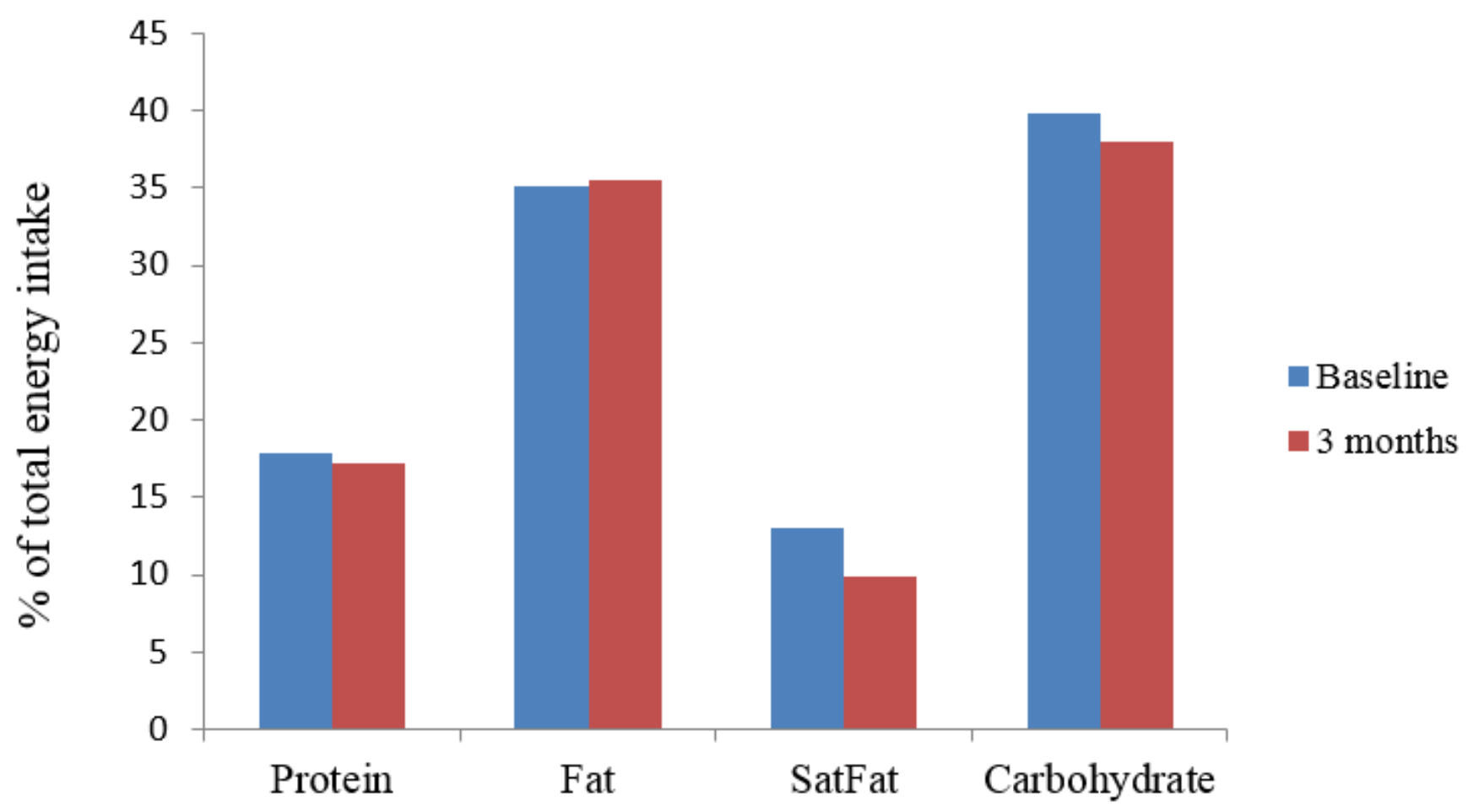




\section{Table 6(on next page)}

Changes in intake of dietary items and nutrients, from baseline to three months. 
2 Table 6. Changes in intake of dietary items and nutrients, from baseline to three months.

\begin{tabular}{lllll}
\hline Dietary Component & $\begin{array}{l}\text { Baseline } \\
\text { Mean (SE) }\end{array}$ & $\begin{array}{l}\text { 3 Months } \\
\text { Mean (SE) }\end{array}$ & $\begin{array}{l}\text { Mean Difference } \\
\text { (95\% CI) }\end{array}$ & $\boldsymbol{p}$ \\
\hline Carbohydrate (total) (g/day) & $246.53(11.20)$ & $234.91(11.00)$ & $-11.63(-30.47-7.22)$ & 0.212 \\
Dietary fibre (total) (g/day) & $31.23(1.86)$ & $32.28(1.60)$ & $1.04(-1.83-3.92)$ & 0.456 \\
Sugar (total) (g/day) & $108.14(7.90)$ & $110.86(7.96)$ & $2.72(-11.32-16.75)$ & 0.690 \\
Glucose (g/day) & $19.00(2.28)$ & $32.30(2.97)$ & $13.22(7.30-19.20)$ & $<\mathbf{0 . 0 0 1}$ \\
Fructose (g/day) & $20.80(2.40)$ & $28.80(2.80)$ & $8.55(2.80-14.30)$ & $\mathbf{0 . 0 0 6}$ \\
Sucrose (g/day) & $35.30(4.80)$ & $24.8(3.50)$ & $-10.56(-17.75-1.37)$ & $\mathbf{0 . 0 2 6}$ \\
Lactose (g/day) & $12.80(1.53)$ & $6.53(1.17)$ & $-6.28(-9.70-2.80)$ & $\mathbf{0 . 0 0 1}$ \\
Folate (total) ( $\mu$ g/day) & $537.00(43.50)$ & $564.00(40.40)$ & $27.00(-31.00-85.40)$ & 0.340 \\
Vitamin C (mg/day) & $133.60(13.20)$ & $169.40(22.40)$ & $35.90(-1.03-72.80)$ & 0.056 \\
Vitamin E (mg/day) & $18.60(4.90)$ & $26.53(5.46)$ & $7.94(3.18-12.70)$ & $\mathbf{0 . 0 0 5}$ \\
Vegetables (servings/day) & $2.80(0.28)$ & $2.63(0.31)$ & $-0.18(-1.13-0.78)$ & 0.705 \\
Broccoli (servings/week) & $1.58(0.27)$ & $2.42(0.45)$ & $0.84(-0.19-1.49)$ & $\mathbf{0 . 0 1 4}$ \\
Sofrito sauce (servings/week) & $1.53(0.45)$ & $2.40(0.47)$ & $0.88(0.28-1.47)$ & $\mathbf{0 . 0 0 6}$ \\
Fruit* (servings/day) & $2.78(0.49)$ & $2.50(0.31)$ & $-0.28(-1.01-0.46)$ & 0.440 \\
Pomegranate (servings/day) & $0.05(0.05)$ & $1.28(0.16)$ & $1.23(0.86-1.59)$ & $<\mathbf{0 . 0 0 1}$ \\
Sweetened beverages & $0.51(0.20)$ & $0.15(0.06)$ & $-0.35(-0.70-0.01)$ & $\mathbf{0 . 0 4 6}$ \\
(servings/week) & $4.38(1.01)$ & $2.05(0.55)$ & $-2.33(-3.82-0.83)$ & $\mathbf{0 . 0 0 4}$ \\
Cakes and biscuits (servings/week) & $0.35(0.17)$ & $1.13(0.30)$ & $0.78(-0.28-1.84)$ & $\mathbf{0 . 0 0 4}$ \\
Green tea (cups/day) & &
\end{tabular}

3 g, grams; SE, standard error; CI, confidence interval; * All fruit and fruit juice, including pomegranate. 


\section{Table 7 (on next page)}

Changes in protein intake from baseline to three months. 
2 Table 7. Changes in protein intake from baseline to three months.

\begin{tabular}{lllll}
\hline \multirow{2}{*}{ Dietary Component } & $\begin{array}{l}\text { Baseline Mean } \\
\text { (SE) }\end{array}$ & $\begin{array}{l}\text { 3 Months } \\
\text { Mean (SE) }\end{array}$ & $\begin{array}{l}\text { Mean Difference } \\
\text { (95\% CI) }\end{array}$ & $\boldsymbol{p}$ \\
\hline Protein (g/day) & $106.73(5.52)$ & $99.49(4.99)$ & $-7.24(-17.32-2.85)$ & 0.149 \\
Red \& processed meat (servings/week) & $3.89(0.48)$ & $1.94(0.36)$ & $-1.95(-2.59-1.32)$ & $<\mathbf{0 . 0 0 1}$ \\
Fish (servings/week) & $1.65(0.20)$ & $3.48(0.46)$ & $1.83(0.91-2.74)$ & $<\mathbf{0 . 0 0 1}$ \\
Legumes (servings/week) & $2.37(0.58)$ & $3.78(0.46)$ & $1.41(0.48-2.34)$ & $\mathbf{0 . 0 0 5}$ \\
\hline
\end{tabular}

3 SE, standard error: $\mathrm{CI}$, confidence interval.

4

5 